\title{
Caution Ahead: Traffic Accidents in Cuba
}

\section{Conner Gorry MA}

The call came from Calixto García University Hospital: Alfredo shattered his leg in a head-on collision driving from Havana to the beach. After emergency surgery and several weeks of intensive physical rehabilitation, Alfredo is back on two feet.

Messages flooded in, my phone vibrating off the table: Manolo and his son were being examined at Havana's Carlos J. Finlay Military Hospital after his Lada was nearly totaled in a late-afternoon crash. Both father and son are fine (the Lada, however, is not).

Then there was that other call, the one I most fear since I've lived the experience once previously here in Cuba: a friend was killed in a traffic accident-she was 30 years young and with a future so promising, her tragic death strains comprehension.

All these events happened in the past six weeks and they all had two factors in common: each occurred on a Sunday and all of them were preventable.

According to data released in November 2021 from Cuba's National Commission on Traffic Safety (CNSV), Sunday is the most lethal day to be on Cuban roads, with one fatality for each 11 accidents, while Friday, between 3 PM and 6 PM is the most accident-prone, with $20 \%$ of all accidents occurring at this time.[1]

Analysis provided by CNSV found the most common causes of traffic accidents in Cuba for the first nine months of 2021 were: irresponsible drivers and pedestrians; technical problems with the vehicles involved; and above all, inattentive drivers who did not have proper control of their vehicles at the time of the accident. Drilling down further, data revealed that speeding and right-of-way violations were involved in most accidents, while $17 \%$ of drivers were legally drunk according to breathalyzer tests measuring blood alcohol content (BAC) at the time of the accident in question.[2]

\section{Both the number of accidents-5612-and total fatalities-350- increased in 2021}

While official sources accentuated the positive regarding the grim reality of traffic accidents in the country-highlighting the decrease in accidents between 2015 and 2020 and the $13 \%$ drop in people injured in road accidents from 2020 to 2021[3]the bigger picture is more sobering.

First, both the number of accidents 5612 and total fatalities (350) increased in 2021, representing a jump of $1 \%-2 \%$ from the previous year.[3] More importantly, the period under study for 2021 was between January and September, as opposed to the full 12-month calendar year for 2020_meaning there were more accidents and deaths in $25 \%$ less time. The context in which these accidents occurred is also troubling: not only was the country closed to tourism during the time studied, but nearly all non-essential interprovincial travel was suspended and a countrywide curfew of 9 PM was in place. All this reveals that accidents, including fatal ones, increased in a shorter timeframe, during which traffic volume was drastically reduced.
Other factors contributing to the problem according to CNSV include unlicensed drivers-54\% of accidents involved drivers with no license, representing over 16,000 drivers in total.[3,4] The majority of them were driving electric motorcycles, vehicles that prior to 2021 did not require license plates either, meaning a driver fleeing the scene of an accident would be almost impossible to locate. Obtaining and renewing drivers' licenses, plus vehicle inspections and registration, were all suspended due to COVID-19 throughout the period studied. Since motor vehicle services re-opened in mid-November, the expectation is that the trifecta of unlicensed drivers, technical defects and vehicles without plates will gradually improve. However, the backlog, combined with the infamously sluggish bureaucracy, means the impact will not be immediately felt.

There are other, more complicated and costly reasons behind traffic accidents as well, lack of infrastructure investment and improvements chief among them. Street lighting in Cuba is dangerously deficient, even on main city thoroughfares and four-lane highways, making night driving especially challenging. Roadway signage, though vastly improved over the past five years, is still lacking and sometimes confusing, which can lead to indecisive or conversely, abrupt maneuvers behind the wheelboth perilous.

Road conditions themselves are also a major hazard as anyone who has driven here knows: drivers routinely swerve brusquely to avoid the ubiquitous potholes common to Cuban streets, while motorcycle riders must keep their eyes pegged to the asphalt directly in front of them or risk being tossed in the air like a popped kernel of corn. Poor geometric design on certain roads, including sight distance, curve radius, horizontal and vertical alignments and super-elevation, can also affect road safety.[5] Currently there are over 2000 ongoing studies related to improving sight distance, and 22,000 traffic signs are being installed.[3] Both initiatives should help. Unfortunately, Cuba's ongoing economic crisis, compounded by the pandemic and strengthened US sanctions, pits roadway investment and maintenance against other, more immediate priorities.

The CNSV underscored the role of driver and pedestrian responsibility as a major cause of traffic accidents. Jaywalking and stepping into oncoming traffic is an all-too-common practice here. Indeed, data shows that $45 \%$ of accidents were caused by pedestrians and $38 \%$ of the injured in all accidents in the period studied were 66 years or older.[3] Speeding, drunk driving and texting/talking on a cell phone while at the wheel are other dangerous practices that must be addressed. The fact that accidents (of all types) have been the fifth cause of death in Cuba for several years running[6] lays bare the urgency of the problem.

Although there is little good news on Cuba's traffic safety front, the benefit of such data is that it allows for policy analysis and action to reverse the deadly trend that saw 23 accidents, 15 people injured and one killed every day in Cuba between January and September, 2021.[3] While so much is out of our control in these pandemic times, navigating our roads carefully, soberly-whether driving, walking or cycling -is clearly within our command. Mh- 


\section{Viewpoint}

\section{REFERENCES}

1. Discreto aumento de accidentes de tránsito en Cuba en 2021 [Internet]. Havana: Prensa Latina; 2021 Nov 5 [cited 2021 Dec 20]. Available at: https:// www.prensa-latina.cu/2021/11/05/discreto-aumento-de-accidentes-de-tran sito-en-cuba-en-2021. Spanish.

2. OnCubaNews [Internet]. Havana: OnCubaNews; c2021. Cuba. Más de 5 mil accidentes de tránsito en Cuba en 2021, con 350 fallecidos; 2021 Nov 5 [cited 2021 Dec 20]; [about 2 p.]. Available at: https://oncubanews.com/cuba/mas-de-5-mil -accidentes-de-transito-en-cuba-en-2021-con-350-fallecidos/?amp. Spanish.

3. Antón Rodríguez S. Que la movilidad no incida en la accidentalidad. Granma [Internet]. 2021 Nov 8 [cited 2021 Dec 20]; Cuba:[about 2 p.]. Available at: https://www.granma.cu/cuba/2021-11-08/que-el-aumento-de-la-movilidad-noincida-en-la-accidentalidad-08-11-2021-18-11-38. Spanish.

4. Pérez Muñoa D. Accidentes de tránsito en 2021: más de la mitad reportan al menos una víctima [Internet]. Havana: Agencia Cubana de Noticias (ACN); 2021 Nov 5 [cited 2021 Dec 20]. Available at: http://www.acn.cu/cuba/86793 -accidentes-de-transito-en-2021-mas-de-la-mitad-reportan-al-menos-una -victima-fotos. Spanish.

5. Hasibul Islam MD, Hamid H, Hua Law T, Azarkerdar A. Relationship of accident rates and road geometric design. IOP Conference Series Earth
Environ Sc [Internet]; 2019 Nov [cited 2021 Dec 20];357(1):012040. DOI: 10.1088/1755-1315/357/1/012040. Available at: https://www.researchgate. net/publication/337500124_Relationship_of_Accident_Rates_and_Road_Geo metric_Design

6. National Health Statistics and Medical Records Division (CU). Anuario Estadística de Salud 2020. Havana: Ministry of Public Health (CU); 2021. p. 44. Spanish.

\section{THE AUTHOR}

Conner Gorry (cconnergo@gmail.com), Havana-based journalist and Senior Editor of MEDICC Review, holds a master's degree in political science and has been reporting on the Cuban health system since 2004. https://orcid.org/0000-0001-8212-3386.

Submitted: December 21, 2021

Approved for publication: December 23, 2021

Disclosures: The author is Senior Editor of MEDICC Review. 